\title{
Lauter, Paul (2020) Our Sixties: An Activist's History, Rochester University Press.
}

\section{Review by Michael Zweig}

The first question one asks when considering a memoir is: Why would I want to know about this person? In Paul Lauter's case, there are many reasons, especially for anyone interested in how life experience draws a person into political activity, and how that activity leads them to groundbreaking progressive political action.

Lauter was born in 1932. He was fourteen years old when the first baby boomer came along, having grown up before most of the students who built the core social movements referred to as 'the Sixties.' Nonetheless, in his memoir Lauter lays claim, in its title and in the arc of his development, to that tumultuous decade, which stretched into the early '70s. By 1960, Lauter had already spent eight years teaching at several colleges and universities. He had written a number of articles in The Nation, The New Republic, and other liberal publications. He had become the father of two boys, and saw his first wife, whom we know only as Tris, 'dump' him, seemingly due to the strains a '50s marriage put on a $\mathrm{PhD}$ wife following her husband from place to place as his job prospects unfolded.

Lauter describes his 'political coming out' in the act of leafleting a showing of the movie On the Beach on behalf of the Committee for a Sane Nuclear Policy (SANE) early in 1960, while teaching at UMass Amherst. Here he makes the critically important point that political action, even in such a small way as leafleting a movie audience, is 'when the butterfly emerges from the cocoon,' when a person enters the public realm of social practice from the interior world of thought. The rest of the book recounts the paths Lauter has followed, in which theory and practice have continually intertwined to shape his personal development.

Readers will find here revealing thumbnail sketches of important 'Sixties' organizations, in which Lauter sometimes acted as a functionary, sometimes played leading roles. Among them are the American Friends Service Committee (AFSC), the Council of Federated Organizations (COFO, which led Freedom Summer activities in Mississippi in 1964), Students for a Democratic Society (SDS), the New University Conference (NUC), and the United States Servicemen's Fund (USSF). Lauter also was the staff person for Resist, the organizational arm of the 1967 'A Call to Resist Illegitimate Authority,' helpfully reprinted as an appendix to this book, and he co-founded the Feminist Press with his long-time partner Florence Howe. These glimpses into the Movement provide interesting historical information, placing Lauter's personal growth in that context. Readers will probably be most familiar with Paul Lauter as the editor of the Heath Anthology of American Literature, and as a guiding light for the newsletter/journal Radical Teacher. These landmark publications played central roles in transforming North American approaches to pedagogy and to the literary canon.

Lauter explains how his experiences in the 1964 Mississippi Freedom Schools helped give rise to these contributions. His role in the Freedom Schools was to bring in films on nonviolence and teach Negro (as it was called then) history and literature. The students were Black people of all ages who were preparing to challenge the murderous repression Mississippi whites had unleashed against Black people attempting to register to vote. This was his introduction to 'education for insurgency,' altogether different from Lauter's previous teaching experience. 
Lauter reflects on this contrast in his juxtaposition of the anti-Vietnam War Teach-ins that started at the University of Michigan in March 1965 to the Teaching About Peace Conference he helped organize for the American Friends in June 1964, just before he went to Mississippi. That conference had nothing like the impact of the Michigan Teach-in, Lauter says, because it was oriented towards policy makers while the Teach-in was oriented towards the activists who would build the anti-war movement.

Lauter's understanding of his Freedom School experience sharpened when he was hired to lead the transformation of the Morgan Community School in Washington, D.C to 'community control' in 1967. While he had thoughts of implementing the COFO Freedom School model in D.C., he found it was impossible because the Morgan project lacked two central ingredients COFO provided: clear organization and genuine community engagement. Without these, Lauter found, there could be no education for insurgency. The project failed. Lauter explains how these involvements shaped his view of the limitations inherent in traditional teaching methods, which he characterizes as the 'banking theory of knowledge,' in which the teacher is the repository of knowledge to be transmitted to passive student receptacles. Instead, he came to champion 'student-centered teaching' that brings out what students know as the basis for what more they learn. This in turn led Lauter to understand the need to confront the standard literary Canon: 'The primary cry of the movement was for representation, that is, for being heard, not as the inheritors of 'the whole of the literature of Europe from Homer,' but as those who had been marginalized by that very formulation.'

These experiences shaped the content and orientation of the Radical Teacher, which Lauter and Florence Howe started as a newsletter of the New University Conference in 1969-1970. The publication is active to this day, with Lauter on its editorial board. And the challenge to the Canon led Lauter to edit the Heath Anthology, a vast compendium of writing from sources far beyond standard Canon fare, in which we hear the voices of all communities.

For all his skill as a writer, Lauter left me frustrated in many places where he tells a story without explaining its relevance to the theme of the book, or just leaves the story unfinished. He tells us there was a debate about the meaning of 'conscience' in the draft-avoiding conscientious objector status, but not the content of the debate. We hear of several sexual relationships with women, but for no apparent purpose. We hear about fierce debates in the feminist movement, but not what he learned in the context of his long relationship with Florence Howe and the development of the Feminist Press.

Towards the end of his memoir, Lauter explores the difficulties of bringing working class literature and art into the college classroom. He talks about how the working-class literature of struggle "wore my younger students down.' He reflects on the relative disappearance of class in relation to race and gender as identities from the 1970s on, and the reluctance of academic leaders to accept the 'art of combat' that suffuses working-class culture. For practitioners of working-class studies, a deeper exploration of these experiences would have been welcome.

Lauter has lived through decades of unstable academic employment interlaced with jobs as an organizer in various movements. This can serve as a model for many young activists these days, for whom this book will be a valuable resource.

\section{Reviewer Bio}

Michael Zweig is emeritus professor of economics and founding director of the Center for Study of Working Class Life at the State University of New York at Stony Brook. A long-time activist with roots in the Students for a Democratic Society in the 1960s, he is one of the founders of the WorkingClass Studies Association and author of Working-Class Majority: America's Best Kept Secret. 